\title{
ABUNDANCE AND DISTRIBUTION OF BLOOD CLAMS (Anadara granosa) IN COASTAL WATERS OF MEKARBARU VILLAGE KEPULAUAN MERANTI
}

\author{
Hendra Tri Sulistio $^{1^{*}}$, Efriyeldi ${ }^{2}$, Musrifin Ghalib ${ }^{2}$ \\ ${ }^{1}$ Student of The Faculty of Fisheries and Marine Science University of Riau, Pekanbaru \\ ${ }^{2}$ Lecturer at The Faculty of Fisheries and Marine Science University of Riau, Pekanbaru \\ *trisulistioh@gmail.com
}

\begin{abstract}
This research is expected to find out how abundance and distribution of blood clams (Anadara Granosa) in coastal waters of Mekarbaru village, Kepulauan Meranti District. In good conditions or during the season in a particular month there is more capture compared to when it is not in season. Analyze using descriptive analysis research methods using survey methods. The materials used in this study were blood clam samples (A.granosa), and aquades for tool rinsing. The results of this study can be concluded that the average abundance of blood clams of $A$. granosa in the coastal waters of Mekarbaru Village, Kepulauan Meranti District is different. The highest average blood clam abundance was found at station III which was $21.86 \mathrm{Ind} / \mathrm{m}^{2}$ and the lowest was at station II which was $19.63 \mathrm{Ind} / \mathrm{m}^{2}$. The size distribution of blood clams A. granosa can be seen that dominating is the size of $<25 \mathrm{~mm}$ (small), while the size of 25-30 mm (Medium) is only found at each station. The abundance of small blood clams A. granosa is influenced by the content of sediment organic matter and water quality in the coastal waters of Mekarbaru Village, Kepulauan Meranti Regency.
\end{abstract}

Keywords: Abundance, distribution, blood shells, coastal water

\section{PENDAHULUAN}

Perairan pantai tergolong sebagai kawasan perairan yang subur, namun tidak semua organisme dapat hidup di setiap kawasan. Hal ini dikarenakan setiap organisme membutuhkan lingkungan yang berbeda-beda. Organisme yang mampu hidup di perairan pantaiantara lain dari filum mollusca.

Kerang yang termasuk ke dalam kelas bivalva mempunyai bentuk dan ukuran cangkang yang bervariasi.Variasi bentuk cangkang ini sangat penting dalam menentukan jenis-jenis bivalva (Kira, 1965).Bivalva dalam kelompok moluska berdasarkan karakteristik memiliki kaki, insang dan dua cangkang.Kerang merupakan hewan yang sukses hidup di lingkungan akuatik (Talman dan Knough,
2001). Kerang hidup pada semua tipe perairan yaitu air tawar, estuari dan perairan laut.

Kerang darah (Anadara granosa) merupakan salah satu jenis kerang yang berpotensi dan bernilai ekonomis tinggi untuk dikembangkan sebagai sumber protein dan mineral untuk memenuhi kebutuhan pangan masyarakat. Dalam upaya mempertahankan kelangsungan hidupnya, makhluk hidup berinteraksi dengan lingkungan dan cenderung untuk memilih kondisi lingkungan serta tipe habitat yang terbaik untuk tetap tumbuh dan berkembangbiak. Faktor-faktor yang mempengaruhi pertumbuhan kerang yaitu musim, suhu, salinitas, substrat, makanan, dan faktor kimia air lainnya yang berbeda- 
beda pada masing-masing daerah. Kerang darah banyak ditemukan pada substrat yang berlumpur di muara sungai, bersifat infauna yaitu hidup dengan cara membenamkan diri di bawah permukaan lumpur. Ciri-ciri dari kerang darah adalah mempunyai dua keping cangkang yang tebal, ellips, dan kedua sisi sama, kurang lebih 20 rib. Cangkang berwarna putih ditutupi periostrakum yang berwarna kuning kecoklatan sampai coklat kehitaman. Ukuran kerang dewasa 6-9 cm (Latifah, 2011).

Kerang darah (A. granosa) memiliki kebiasaan makan dengan cara menyaring (filter feeder), daya tahan hidupnya yang tinggi dan dalam jumlah yang berlimpah kerang darah dapat dimanfaatkan untuk mengatasi pencemaran perairan akibat padatan tersuspensi dengan demikian hewan ini dapat membantu dalam usaha penjernihan air. Kemampuan kerang darah (A. granosa) dalam menyaring bahanbahan tersuspensi dapat dimanfaatkan sebagai biofilter polutan, sehingga dapat berfungsi sebagai cleaning agent atau membantu dalam mengurangi padatan tersuspensi.

Masyarakat di perairan pesisir Desa Mekarbaru pada umumnya sudah lama mengenal dan memanfaatkan kerang sebagai sumber pangan, karena selain rasanya enak, kerang juga mengandung protein dan nilai ekonomis yang tinggi. Tingginya nilai jual kerang tersebut mengakibatkan tingginya aktifitas penangkapan kerang tanpa memperhatikan kelestariannya. Jika masyarakat melakukan penangkapan secara terus-menerus dikhawatirkan akan berakibat buruk bagi keberadaan (kelestarian) populasinya. Penelitian mengenai kelimpahan dan distribusi kerang darah (A. granosa) di Desa Mekarbaru Kabupaten Kepulauan Meranti belum ada. Berdasarkan hal tersebut dirasa penting untuk dilakukan penelitian mengenai kelimpahan dan distribusi kerang darah (A. granosa) di Desa Mekarbaru Kabupaten Kepulauan Meranti.
Perumusan masalah penelitian ini adalah untuk mengetahui bagaimana kelimpahan dan distribusi kerang darah di perairan pesisir Desa Mekarbaru Kecamatan Rangsang Barat Kabupaten Kepulauan Meranti,Pada kondisi yang bagus atau pada saat musim pada bulan tertentu terjadi penangkapan lebih banyak dibandingkan pada saat tidak musimnya.

\section{METODE PENELITIAN}

Metode yang digunakan dalam penelitian adalah metode survei. Sampel penelitian diperoleh di lapangan dan kemudian dianalisis di Laboratorium Biologi Laut Jurusan Ilmu Kelautan Fakultas Perikanan dan Kelautan Universitas Riau.

Kelimpahan suatu organisme dalam suatu perairan dapat dinyatakan sebagai jumlah individu persatuan luas atau volume (Odum, 1993). Perhitungan kelimpahan menggunakan rumus (Brower et al., 1990).

$$
K=\frac{n i}{A}
$$

Keterangan :

$K=$ Kelimpahan Suatu Jenis $\left(\mathrm{Ind} / \mathrm{m}^{2}\right)$

$n i=$ Jumlah Individu Suatu Jenis

$A=$ Luas Area

Untuk mengetahui pola distribusi kerang darah (A. granosa) di Perairan Pesisir Desa Mekarbaru digunakan indeks penyebaran Morisita (Soegianto, 1994) yaitu:

Keterangan :

$$
I d=n \frac{\left(\Sigma x^{2}-\Sigma x\right)}{((\Sigma x) 2-\Sigma x)}
$$

id = Indeks penyebaran Morisita

$N=$ Jumlah plot

$\Sigma \mathrm{x}=$ Jumlah individu disetiap kuadran

$\Sigma \mathrm{x}^{2}=$ Jumlah individu di setiap kuadran di kuadratkan

Untuk menguji hipotesa tentang ketidakacakan dilakukan perhitungan:

$$
\mathbf{X}^{2}=\mathbf{I d}(\Sigma \mathbf{x}-\mathbf{1})+\mathbf{n}-\Sigma \mathbf{x}
$$

dengan $\mathrm{db}=\mathrm{n}-1$ di mana $\mathrm{X}^{2}$ adalah uji statistik untuk indek morisita (distribusi chi-scuare). 
Hasil penyebaran ini dikelompokkan menjadi 3 kriteria yaitu :

(1) Id $<1$ (Penyebaran kerang darah bersifat merata)

(2) Id = 1 (Penyebaran kerang darah bersifat acak)

(3) Id > 1 (Penyebaran kerang darah mengelompok)

Sampel kerang darah (A. granosa) diambil pada setiap stasiun (3 stasiun) dalam satu periode sampling. Dari hasil tangkap setiap stasiun, kerang darahyang telah diperoleh dikelompokkan terlebih dahulu ke dalam 3 ukuran panjang yaitu ukuran kecil $(<25 \mathrm{~mm})$, sedang $(25 \mathrm{~mm}-$ $30 \mathrm{~mm})$ dan besar $(30 \mathrm{~mm}-50 \mathrm{~mm})$ (Afriansyah, 2009).
Hasil analisis data dipresentasikan dalam bentuk tabel dan grafik. Kemudian dibahas dan disimpulkan secara deskriptif. Untuk membandingkan perbedaan kelimpahan antara titik sampling ditempat penelitian maka dilakukan pengujian menggunakan uji Anova. Selanjutnya jika diperoleh adanya perbedaan yang nyata lanjutnya menggunakan uji LSD (Least Significance Different).

\section{HASIL DAN PEMBAHASAN Parameter Kualitas Perairan}

Parameter kualitas perairan sebagai faktor pendukung untuk mengetahui kondisi lingkungan pada saat melakukan penelitian. Hasil pengukuran parameter kualitas perairan pada saat penelitian dilihat pada Tabel 2.

Tabel 2. Parameter Kualitas Perairan di perairan Pesisir Desa Mekarbaru

\begin{tabular}{|c|c|c|c|c|c|c|c|c|c|c|}
\hline \multirow{3}{*}{ No } & \multirow{3}{*}{$\begin{array}{c}\text { Parameter kualitas } \\
\text { perairan }\end{array}$} & \multicolumn{9}{|c|}{ Stasiun/titik sampling } \\
\hline & & \multicolumn{3}{|c|}{ I } & \multicolumn{3}{|c|}{ II } & \multicolumn{3}{|c|}{ III } \\
\hline & & 1 & 2 & 3 & 1 & 2 & 3 & 1 & 2 & 3 \\
\hline \multirow[b]{2}{*}{1} & $\mathrm{pH}$ (unit) & 7 & 7 & 8 & 7 & 7 & 8 & 8 & 7 & 7 \\
\hline & Rata-rata & & 7,3 & & & 7,3 & & \multicolumn{3}{|c|}{7,3} \\
\hline \multirow{2}{*}{2} & Suhu $\left({ }^{0} \mathrm{C}\right)$ & 28 & 28 & 28 & 28 & 28 & 28 & 28 & 28 & 29 \\
\hline & Rata-rata & & 28 & & & 28 & & \multicolumn{3}{|c|}{28,3} \\
\hline \multirow{2}{*}{3} & Salinitas (\%) & 33 & 32 & 32 & 31 & 31 & 30 & 32 & 32 & 33 \\
\hline & Rata-rata & & 32,3 & & \multicolumn{3}{|c|}{31,3} & \multicolumn{3}{|c|}{32,3} \\
\hline \multirow{2}{*}{4} & Kecerahan $(\mathrm{cm})$ & 25 & 26 & 27 & 23 & 24 & 25 & 24 & & 31 \\
\hline & Rata-rata & & 26 & & & 24 & & \multicolumn{3}{|c|}{27,3} \\
\hline
\end{tabular}

Pengukuran kualitas perairan di perairan pesisir Desa Mekarbaru Kabupaten Kepulauan Meranti pada saat penelitian dengan rata-rata $\mathrm{pH}$ air 7,3 , rata-rata pengukuran suhu perairan berkisar 28$28,3^{\circ} \mathrm{C}$, suhu tertinggi $28,3^{\circ} \mathrm{C}$ terdapat pada stasiun III dan suhu terendah terdapat pada stasiun I dan II $28^{\circ} \mathrm{C}$, rata-rata salinitas berkisar 31,3-32,3\%0, salinitas tertinggi yaitu $32,3 \%$ terdapat pada stasiun I dan III, salinitas terendah yaitu 31,3 pada stasiun II, sedangkan rata-rata kecerahan berkisar 24$27,3 \mathrm{~cm}$, kecerahan tertinggi yaitu $27,3 \mathrm{~cm}$ pada stasiun III kecerahan terendah yaitu
$24 \mathrm{~cm}$ pada stasiun II sedangkan nilai kecerahan stasiun I yaitu $26 \mathrm{~cm}$.

\section{Analisis Padatan Tersuspensi}

Hasil pengukuran padatan tersuspensi di perairan pesisir Desa Mekanbaru dilihat pada Tabel 3. Pada tabel tersebut dapat dilihat kandungan padatan tersuspensi berkisar antara 0,20-0,23 gr.

Tabel 3. Padatan Tersuspensi di perairan Pesisir Desa Mekarbaru

\begin{tabular}{c|c}
\hline Stasiun & Kandungan TSS (gr) \\
\hline 1 & 0,24 \\
2 & 0,21 \\
3 & 0,20 \\
\hline
\end{tabular}


Analisis Sampel Sedimen

Dari analisis jenis sedimen di perairan Pesisir Desa Mekarbaru maka diketahui bahwa komposisi fraksi sedimennya sebagai berikut (Tabel 4).

Tabel 4. Tipe Sedimen di perairan Pesisir Desa Mekarbaru

\begin{tabular}{ccccc}
\hline & \multicolumn{4}{c}{ Jenis Sedimen } \\
\cline { 2 - 5 } Stasiun & Kerikil (\%) & Pasir (\%) & Lumpur (\%) & Tipe Sedimen \\
\hline 1 & 0,93 & 15,60 & 83,47 & Lumpur \\
2 & 1,10 & 22,94 & 75,96 & Lumpur \\
3 & 1,03 & 21,83 & 77,14 & Lumpur \\
\hline Rata-rata & 1.02 & 20.12 & 78.85 & Lumpur \\
\hline
\end{tabular}

Berdasarkan Tabel 4 dapat dilihat bahwa rata-rata jenis sedimen didominasi oleh Lumpur.

\section{Bahan Organik Sedimen}

Dari hasil analisis bahan organik sedimendi perairan Pesisir Desa Mekarbaru dapat dilihat pada Tabel 5.

Tabel 5. Bahan Organik Sedimen di perairan Pesisir Desa Mekarbaru.

\begin{tabular}{c|c}
\hline Stasiun & Bahan organik $(\boldsymbol{\%})$ \\
\hline 1 & 4,89 \\
2 & 6,86 \\
3 & 6,95 \\
\hline
\end{tabular}

Tabel 5 dapat dilihat bahwa bahan organik pada masing-masing stasiun berbeda, dimana bahan organik yang terendah terdapat pada stasiun 1 dan yang tertinggi terdapat pada stasiun 3.

\section{Kelimpahan A. granosa}

Dari pengamatan terhadap kelimpahan kerang darah selama penelitian dilaksanakan pada masing-masing titik stasiun di perairan Pesisir Desa Mekarbaru. Lebih jelas dapat dilihat pada Tabel 6.

Tabel 6. Kelimpahan A.granosa di perairan Pesisir Desa Mekarbaru.

\begin{tabular}{|c|c|c|c|c|}
\hline \multirow{2}{*}{ Stasiun } & \multicolumn{3}{|c|}{ Titik Sampling } & \multirow{2}{*}{ Rata-rata (Ind/m $\left.\mathrm{m}^{2}\right)$} \\
\hline & 1 & 2 & 3 & \\
\hline \multirow{3}{*}{ I } & 16 & 19 & 14 & \\
\hline & 42 & 23 & 15 & \\
\hline & 37 & 17 & 14 & \\
\hline$\left(\mathrm{Ind} / \mathrm{m}^{2}\right)$ & 31,6 & 19,6 & 14,3 & 21,83 \\
\hline \multirow{3}{*}{ II } & 10 & 17 & 20 & \\
\hline & 15 & 21 & 30 & \\
\hline & 17 & 18 & 29 & \\
\hline$\left(\right.$ Ind $\left./ m^{2}\right)$ & 14 & 18,6 & 26,3 & 19,63 \\
\hline \multirow{3}{*}{ III } & 7 & 11 & 20 & \\
\hline & 20 & 17 & 19 & \\
\hline & 42 & 34 & 27 & \\
\hline$\left(\right.$ Ind/m m $\left.^{2}\right)$ & 23 & 20,6 & 22 & 21,86 \\
\hline
\end{tabular}


Dari Tabel 6 dapat dilihat bahwa kelimpahan rata-rata kerang darah pada masing-masing stasiun terdapat perbedaan. Rata-rata kelimpahan kerang darah yang tertinggi ditemukan pada stasiun yaitu $21,86 \mathrm{ind} / \mathrm{m}^{2}$ dan yang terendah adalah pada stasiun 2 yaitu $19,63 \mathrm{ind} / \mathrm{m}^{2}$.

Hasil perhitungan Uji ANOVA didapat bahwa kelimpahan kerang darah pada perairan pantai Desa Mekarbaru tidak berbeda nyata dengan nilai signifikan yang diperoleh 0,885 sehingga $\mathrm{p}>0,05$. Oleh karena itu kelimpahan kerang darah tidak berbeda nyata pada setiap stasiun.

\section{Pola SebaranA. granosa}

Pola sebaran merupakan metode untuk menentukan sifat penyebaran suatu komunitas di lokasi penelitian. Pola sebaran kerang darah di perairan Pesisir Desa Mekarbaru dapat dilihat pada Tabel 6.

Tabel 7. Pola sebaran di perairan Pesisir Desa Mekarbaru

\begin{tabular}{cccccc}
\hline Stasiun & $\mathbf{N}$ & $\sum \mathbf{x}$ & $\sum \mathbf{x}^{2}$ & Id & Pola Sebaran \\
\hline 1 & 3 & 65,5 & 1587,21 & 1,08 & Acak \\
2 & 3 & 58,9 & 1233,65 & 1,03 & Acak \\
3 & 3 & 65,6 & 1437,36 & 0,97 & Acak \\
\hline
\end{tabular}

Berdasarkan penjabaran dari Tabel 7 dan setelah dilakukan uji ketidakacakan maka diperoleh nilai $\mathrm{X}^{2}$ untuk ketiga stasiun $<7,38(\mathrm{db}=3-1)$, maka pola sebaran kerang darah (A. granosa) disetiap stasiun adalah $\mathrm{Id}=1$ artinya penyebaran kerang darah bersifat acak.

\section{Distribusi Ukuran A. granosa}

Berdasarkan hasil pengukuran individu kerang di perairan Pesisir Desa Mekarbaru pada setiap stasiun penelitian dapat diketahui bahwa distribusi ukuran kerang di sangat mendominasi ukuran kecil dapat dilihat pada Tabel 8.

Tabel 8. Distribusi ukuran di perairan Pesisir Desa Mekarbaru

\begin{tabular}{cccc}
\hline & & \multicolumn{3}{c}{ Ukuran/Besar } \\
\cline { 2 - 4 } Stasiun & $<25 \mathrm{~mm}(\mathrm{kecil})$ & $25-30 \mathrm{~mm}$ (sedang) & $>30 \mathrm{~mm}$ (besar) \\
\hline 1 & 96 & 2 & Tidak ditemukan \\
2 & 46 & 1 & Tidak ditemukan \\
3 & 54 & 1 & Tidak ditemukan \\
\hline
\end{tabular}

Dari Tabel 8 ukuran kerang darah yang paling mendominasi adalah ukuran $<25 \mathrm{~mm}$ (kecil), sedangkan ukuran 25-30 $\mathrm{mm}$ (sedang) hanya sedikit ditemukan di setiap stasiun. Selanjutnya dapat dilihat grafik distribusi ukuran kerang darah $(A$. granosa) pada masing-masing stasiun penelitian dapat dilihat pada Gambar 1.

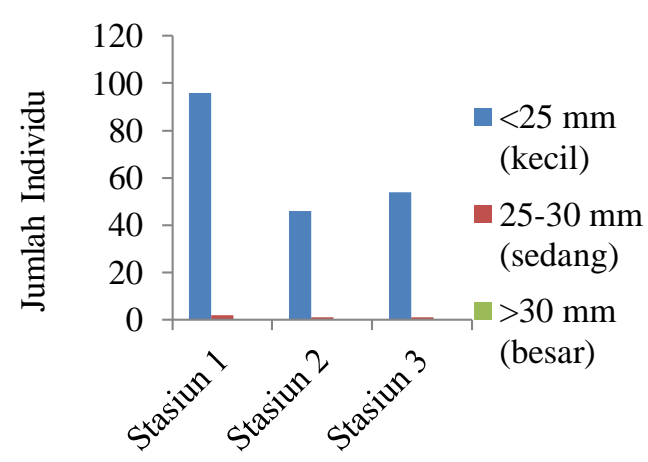

Gambar 1. Distribusi ukuran A. granosa pada masing-masing stasiun penelitian. 


\section{Pembahasan}

\section{Kelimpahan A. granosa}

Perbandingan besar, sedang dan kecilnya jumlah individu, jika $<25 \mathrm{~mm}$ dikatakan kecil, 25-30 mm dikatakan sedang dan dikatakan besar jika > $30 \mathrm{~mm}$. Berdasarkan hasil penelitian pada Tabel 5, diketahui bahwa kisaran rata-rata kelimpahan kerang (A.granosa) yang tertinggi yaitu ditemukan pada stasiun 3 yaitu 21,86 ind $/ \mathrm{m}^{2}$ dan yang terendah adalah pada stasiun 2 yaitu $19,3 \mathrm{ind} / \mathrm{m}^{2}$, Jika dihubungkan dengan kualitas perairan tertinggi terdapat pada stasiun III, maka dapat disimpulkan pada stasiun III kualitas perairan masih baik untuk habitat kerang darah, yang memerlukan $\mathrm{pH}$, suhu, salinitas dan kecerahan.

Pengukuran kualitas perairan di perairan pesisir Desa Mekarbaru Kabupaten Kepulauan Meranti pada saat penelitian dengan stasiun I, II dan III mempunyai rata-rata $\mathrm{pH}$ air sama dengan 7,3 (unit). Nilai $\mathrm{pH}$ yang ideal bagi kehidupan organisme pada umumnya antara 7-8,5. Kondisi perairan yang sangat asam maupun sangat basa akan membahayakan kelangsungan hidup organisme karena akan menyebabkan terjadinya gangguan metabolisme dan respirasi (Barus, 2004). Menurut Romimohtarto (1985) pH permukaan laut indonesia pada umumnya antara 6,0-8,5. Perubahan nilai $\mathrm{pH}$ mempunyai akibat buruk terhadap kehidupan biota laut.

Rata-rata pengukuran suhu perairan berkisar $28-28,3^{\circ} \mathrm{C}$, suhu tertinggi $28,3^{\circ} \mathrm{C}$ terdapat pada stasiun III dan suhu terendah terdapat pada stasiun I dan II $28^{\circ} \mathrm{C}$. Odum (1993) menyatakan suhu sekitar $30^{\circ} \mathrm{C}$ ekosistem akuatik dipengaruhi oleh intensitas matahari, ketinggian geografis dan faktor kenopi (penutup vegetasi) dari pepohonan yang tumbuh disekitarnya. Menurut Sitorus (2008) suhu yang optimal untuk kelangsungan bivalva berkisaran antara $25-31^{\circ} \mathrm{C}$. Sedangkan menurut Brotowidjoyo et al. (1995) A. granosa banyak ditemukan di perairan estuari dengan substrat lumpur dan pasir dengan suhu sekitar $30^{\circ} \mathrm{C}$ akan merangsang Anadara betina untuk bertelur.

Rata-rata salinitas berkisar 31,3$32,3 \%$, salinitas tertinggi yaitu 32,3\%o terdapat pada stasiun I dan III, salinitas terendah yaitu $31,3 \%$ pada stasiun II. Hutabarat dan Evans (1985) menyatakan bahwa salinitas di perairan terbuka bisa mencapai $35 \%$ sedangkan di perairan pantai akan lebih rendah disebabkan terjadinya proses pengenceran, misalnya pengaruh sungai, sehingga salinitas turun. Salinitas menunjukkan jumlah ion-ion terlarut. Perubahan salinitas berpengaruh pada proses difusi dan osmotik. Kerang mengatur osmotik tubuh secara intra selluler (Levinton, 1982). Sedangkan ratarata kecerahan berkisar 24-27,3 cm, kecerahan tertinggi yaitu $27,3 \mathrm{~cm}$ pada stasiun III kecerahan terendah yaitu $24 \mathrm{~cm}$ pada stasiun II sedangkan nilai kecerahan stasiun I yaitu $26 \mathrm{~cm}$. Kecerahan adalah kemampuan cahaya matahari untuk dapat menembus perairan, semakin tinggi kecerahan maka semakin dalam penetrasi cahaya matahari ke dalam perairan tersebut (Nybakken,1992). Kecerahan yang besar umumnya terdapat diperairan laut sedang keccerahan yang rendah terdapat di daerah muara (Soedharma, 1994).

Dilihat dari stasiun III rata-rata kelimpahan kerang darah yang tertinggi ditemukan pada stasiun ini yaitu dengan nilai 21,86 ind $/ \mathrm{m}^{2}$. Disebabkan karena daerah stasiun III memiliki kandungan bahan organik yang tinggi dibandingkan stasiun yang lainnya. Berdasarkan hasil analisis jenis fraksi sedimen, maka jenis fraksi sedimen yang ada di daerah stasiun III ini didominasi oleh lumpur. Lokasi penelitian ini sangat mendukung habitat kerang darah (A. granosa) karena kerang darah hidup dengan cara membenamkan diri di dalam lumpur.

Rata-rata kelimpahan kerang darah terendah terdapat pada stasiun II yaitu 
dengan nilai $19,63 \mathrm{Ind} / \mathrm{m}^{2}$ ini dikarenakan berada dekat dengan muara sungai. Muara sungai merupakan daerah peralihan antara air tawar dan air laut, kerang darah biasanya lebih banyak dijumpai pada daerah yang lebih jauh dari muara suangai karena muara sungai merupakan daerah yang paling banyak terkena dampak dari ketiga faktor yaitu bahan pencemar dan kegiatan perikanan yang mengeksploitasi kerang seacara berlebihan (Dahuri et al,. 1996). Menurut Broom (1985), A. granosa dapat ditemukan disubstrat lumpur berpasir tetapi jumlah populasi tertinggi ditemukan dilumpur halus yang ditumbuhi hutan bakau dan mangrove.

Stasiun I rata-rata kelimpahan kerang darah adalah 21,83 ind $/ \mathrm{m}^{2}$. Di stasiun I rata-rata kelimpahan kerang darah tidak berbeda jauh dengan stasiun III hal ini disebabkan karena daerah stasiun I terletak dekat dengan hutan mangrove yang salah satu fungsinya sebagai sumber nutrien tertinggi. Kandungan padatan tersuspensi stasiun I tertinggi terdapat pada stasiun I yaitu 0,24 gr dan jenis sedimen di stasiun I didominasi oleh lumpur yang paling tinggi jika dibandingkan dengan stasiun lain. Menurut Shofiyanti dan Siswanto (2013) dikatakan bahwa stasiun dengan konsentrasi TSS tinggi merupakan daerah dengan dominasi substrat berlumpur.

Pada substrat pasir berlumpur, kandungan oksigen relatif lebih besar dibandingkan pada substrat yang halus, karena pada substrat pasir berlumpur terdapat pori udara yang memungkinkan terjadinya percampurang yang lebih intensif dengan air diatasnya, tetapi pada substrat pasir berlumpur ini tidak banyak terdapat nutrien, sedangkan pada yang lebih halus, walaupun oksigen sangat terbatas tapi cukup tersedia nutrien dalam jumlah yang besar (Woodin, 1976).

\section{Pola Sebaran A. granosa}

Pola sebaran di alam dapat dikelompokkan atas tiga bentuk, yaitu bentuk teratur atau merata apabila individuindividunya tersebar meratadi lokasi penyebarannya, bentuk random apabila individu-individunya tersebar secara acak (sembarangan) di daerah tersebut, berkelompok dimana selalu mengelompok dan jarang ditemukan sendiri-sendiri.

Untuk pola sebaran A. granosa disetiap stasiun di perairan pesisir Desa mekarbaru bersifat acak, menurut pendapat saya sedimen yang terdapat di desa mekarbaru adalah didominasi oleh lumpur dan lumpur sebagai habitatnya, oleh karena itu dihitung berdasarkan indeks sebaran morista adalah Id $=1$ yang artinya penyebaran kerang darah bersifat acak. Dari analisis jenis sedimen di perairan pesisir Desa Mekarbaru diketahui bahwa rata-rata jenis sedimen didominasi oleh lumpur.

\section{Distribusi Ukuran A. granosa}

Berdasarkan hasil analisis terhadap distribusi ukuran panjang kerang darah, didapatkan bahwa ukuran yang paling dominan adalah ukuran antara $<25 \mathrm{~mm}$ (kecil). sedangkan ukuran 25-30 mm (Sedang) hanya sedikit ditemukan di setiap stasiun dan ukuran $>30 \mathrm{~mm}$ (besar) tidak ditemukan sama sekali kerang darah $(A$. granosa) di perairan Desa Mekarbaru Kabupaten Kepulauan Meranti.

Selain itu juga pertumbuhan kerang darah dapat berbeda-beda sesuai dengan pendapat Nurdin et al., (2006) menyatakan spesies yang sama pada lokasi yang berbeda akan memiliki pertumbuhan yang berbeda karena adanya perbedaan faktor yang mempengaruhi pertumbuhan tersebut. Pertumbuhan kerang darah dipengaruhi oleh ketersediaan makanan, suhu, musim, dan faktor kimia lainnya yang berbeda untuk masing-masing tempat. Hasil penelitian Broom (1985), kerang darah 
termasuk dalam tipe biota yang memijah beberapa kali sepanjang tahun

\section{KESIMPULAN DAN SARAN Kesimpulan}

Hasil penelitian ini dapat disimpulkan bahwa rata-rata kelimpahan kerang darah A. granosa di perairan pesisir Desa Mekarbaru Kabupaten Kepulauan Meranti bahwa pada masing-masing stasiun terdapat perbedaan. Rata-rata kelimpahan kerang darah yang tertinggi ditemukan pada stasiun III yaitu $21,86 \mathrm{Ind} / \mathrm{m}^{2}$ dan yang terendah adalah pada stasiunII yaitu 19,63 Ind $/ \mathrm{m}^{2}$.

Distribusi ukuran kerang darah A.granosa dapat diketahui bahwa mendominasi adalah ukuran $<25 \mathrm{~mm}$ (kecil), sedangkan ukuran 25-30 mm (Sedang) hanya sedikit ditemukan di setiap stasiun. Kelimpahan kerang darah $A$. granosa berukuran kecil dipengaruhi oleh kandungan bahan organik sedimen dan kualitas air di perairan Pesisir Desa Mekarbaru Kabupaten Kepulauan Meranti.

\section{Saran}

Pada penelitian ini hanya menggambarkan kelimpahan kerang darah A.granosa secara umum.Disarankan untuk peneliti selanjutnya dapat meneliti secara lebih dalam mengenai kelimpahan dan distribusi kerang darah $A$. granosa Kemudian penulis juga menyarankan kepada masyarakat pesisir Desa Mekarbaru Kepulauan Meranti supaya menjaga kondisi vegetasi mangrove yang ada agar tidak punah.

\section{DAFTAR PUSTAKA}

1. Afriansyah, A. (2009). Konsentrasi Kadmium (Cd) dan Tembaga (Cu) dalam Air, Seston, Kerang dan Fraksinasinya dalam Sedimen di Perairan Delta Berau, Kalimantan Timur. Skripsi. Program Studi ilmu dan Teknologi Kelautan Fakultas Perikanan dan Ilmu Kelautan IPB. Bogor.

2. Barus, T.A. (2004). Pengantar Limnologi Studi Leksono Tentang Ekosistem Air Dan Daratan. USU Perss. Medan.

3. Broom, M.J. (1985). The Biology and Culture of Marine Bivalvae Molluscs of Genus Anadara. (p. 37). International Center for Living Aquatic Resources Management. Manila.

4. Brotowidjoyo, M.D., T. Djoko dan M. Eko. (1995). Pengantar Lingkungan Perairan Dan Budidaya Air. (p. 64). Penerbit Liberty. Yogyakarta.

5. Brower, J.Z., C. Jerrold, and V. Ende. (1990). Field and Laboratory Methods for General Zoology. (p. 162). Third edition. United States of America: W.M.C Brown Publisher. America.

6. Dahuri, R., J. Rais., S.P. Ginting, dan M.J. Sitepu, (1996). Pengelolaan Sumberdaya Hayati Wilayah Pesisir dan Laut Secara Terpadu. (p. 305). Jakarta. Pradya Pramitha.

7. Hutabarat, S dan S.M. Evans. (1985). Pengantar Oseaonografi. (p.159). Universitas Indonesia Press. Jakarta.

8. Kira, T. (1976). Shell of The Western Pasific in Colour. Vol I \& II Hoikusha Publ, Co, (Osaka) Japan.

9. Latifah, A. (2011). Karakteristik Morfologi Kerang Darah. Departemen Teknologi Hasil Perairan. Fakultas Perikanan dan Ilmu Kelautan. Institut Pertanian Bogor. Bogor.

10. Levinton, J.S. (1982). Marine Ecology. (p. 235-269). Prentice Hall, Inc. America. 
11. Nurdin, J., N. Marusin, Izmiarti, A. Asmara, R. Deswandi dan J. Marzuki. (2006). "Kepadatan Populasi dan Pertumbuhan Kerang Darah Anadara antiquate L. (Bivalvia: Arcidae) di Teluk Sungai Pisang, Kota Padang, Sumatera Barat" Makara Sains, Volume 10(2), Pages 96-101.

12. Nybakken. (1992). Biologi Laut, Suatu Pendekatan Ekologi. (p. 459). PT. Gramedia Jakarta.

13. Odum, E.P. (1993). Dasar-Dasar Ekologi. (p. 697) Penterjemahan: T. Samingan dan B. Srigandono. Gajah Mada University Press. Yogyakarta

14. Romimohtarto, K. (1985). Kualitas Air dalam Budidaya Laut. WBL/05/WP-13 Bandar Lampung 28 Oktb-1 Nov 1985.

15. Shofiyanti, E.R. dan A.D. Siswanto. (2013). Karakteristik Arus Permukaan dan Konsentrasi Total Suspended Solid (TSS) di Perairan Selat Madura, Kabupaten Bangkalan. Prosiding. Seminar Nasional Perikanan dan Kelautan. FPIK. Undip. Semarang.

16. Sitorus, D.B. (2008). Keanekaragaman dan Distribusi Bivalva serta Kaitannya dengan Faktor Fisika dan Kimia. Sekolah Pasca Sarjana. Universitas Sumatera Utara. (Tidak diterbitkan).

17. Soedharma, D. (1994). Keanekaragaman Makrobentos dan Hubungannya dengan Kualitas Lingkungan Pesisir Teluk Lampung. Jurnal Ilmu-Ilmu Perairan Dan Perikanan Indonesia. Volume II, pages 15-34.

18. Soegianto, A. (1994). Ekologi Kuantitatif. Penerbit Usaha Nasional. Surabaya.

19. Talman, S.G. and M.J. Keough. (2001). Impact of an Exotic elam, Corbula gibba, on the Commercial Scallop Pecten fumatus in Port Phillip Bay, South-East Australia: Evidence of Resource-Restricted Growth in a Subtidal Environment. Marine Ecology Progress Series. Volume 221(1), Pages 135-143

20. Woodin, S.A. (1976). Abdul Larva Interraction In Dense Infauna. Asesemblages : Patterns Of Abudence, Jour. Mar. Res. Volume 34 (1), Pages 25-41. 